\title{
Fortunella margarita Transcriptional Reprogramming Triggered by Xanthomonas citri subsp. citri
}

Abeer A Khalaf ${ }^{1,2^{*}}$, Frederick G Gmitter $\mathrm{Jr}^{2}$, Ana Conesa ${ }^{3}$, Joaquin Dopazo ${ }^{3}$ and Gloria A Moore ${ }^{1}$

\begin{abstract}
Background: Citrus canker disease caused by the bacterial pathogen Xanthomonas citri subsp. citri (Xcc) has become endemic in areas where high temperature, rain, humidity, and windy conditions provide a favourable environment for the dissemination of the bacterium. Xcc is pathogenic on many commercial citrus varieties but appears to elicit an incompatible reaction on the citrus relative Fortunella margarita Swing (kumquat), in the form of a very distinct delayed necrotic response. We have developed subtractive libraries enriched in sequences expressed in kumquat leaves during both early and late stages of the disease. The isolated differentially expressed transcripts were subsequently sequenced. Our results demonstrate how the use of microarray expression profiling can help assign roles to previously uncharacterized genes and elucidate plant pathogenesis-response related mechanisms. This can be considered to be a case study in a citrus relative where high throughput technologies were utilized to understand defence mechanisms in Fortunella and citrus at the molecular level.

Results: CDNAs from sequenced kumquat libraries (ESTs) made from subtracted RNA populations, healthy vs. infected, were used to make this microarray. Of 2054 selected genes on a customized array, 317 were differentially expressed $(P<0.05)$ in Xcc challenged kumquat plants compared to mock-inoculated ones. This study identified components of the incompatible interaction such as reactive oxygen species (ROS) and programmed cell death (PCD). Common defence mechanisms and a number of resistance genes were also identified. In addition, there were a considerable number of differentially regulated genes that had no homologues in the databases. This could be an indication of either a specialized set of genes employed by kumquat in response to canker disease or new defence mechanisms in citrus.

Conclusion: Functional categorization of kumquat Xcc-responsive genes revealed an enhanced defence-related metabolism as well as a number of resistant response-specific genes in the kumquat transcriptome in response to Xcc inoculation. Gene expression profile(s) were analyzed to assemble a comprehensive and inclusive image of the molecular interaction in the kumquat/Xcc system. This was done in order to elucidate molecular mechanisms associated with the development of the hypersensitive response phenotype in kumquat leaves. These data will be used to perform comparisons among citrus species to evaluate means to enhance the host immune responses against bacterial diseases.
\end{abstract}

\section{Background}

Citrus trees are susceptible to a number of diseases with different degrees of economic impact. One of the most severe in terms of economic losses is citrus canker disease (sometimes referred to as Asiatic citrus canker) caused by Xanthomonas citri subsp. citri, (synonym,

\footnotetext{
* Correspondence: abeera@ufl.edu

'Plant Molecular and Cellular Biology Program (PMCB), Horticultural Sciences Department, University of Florida, Gainesville, Fl., 32611,USA

Full list of author information is available at the end of the article
}

Xanthomonas axonopodis pv. citri strain A; Xac-A). Xcc is a biotrophic bacterial phytopathogen that belongs to the genus Xanthomonas of the $\alpha$-subdivision $\mathrm{v}$ within Proteobacteria. Susceptibility to citrus canker disease varies among citrus types and relatives, but most of the commercially grown citrus types are susceptible hosts to Xcc [1]. Disease symptoms include canker lesions on the green aerial parts of the plant as well as fruit; infections can result in both foliar and fruit abscission, thereby decreasing the productivity of affected trees. In
C Biomed Central

(c) 2011 Khalaf et al; licensee BioMed Central Ltd. This is an Open Access article distributed under the terms of the Creative Commons Attribution License (http://creativecommons.org/licenses/by/2.0), which permits unrestricted use, distribution, and reproduction in any medium, provided the original work is properly cited. 
addition there can be reduced profitability as a result of blemished fruit that can be harvested but not sold in the fresh market.

Plants have evolved multiple defence mechanisms to survive pathogen attacks [2]. The first branch of the indispensable plant innate immunity system is triggered by pathogen-associated molecular patterns (PAMPs) such as the lipopolysaccharides (LPSs), peptidoglycan and bacterial flagellin, as well as the chitin and glucan from fungi. The second branch utilizes the nucleotidebinding site-leucine-rich repeat (NBS-LRR) encoded by $\mathrm{R}$ (resistance) genes named the effector-triggered immunity (ETI) [3]. The Xanthomonas spp. phytobacterial pathogens have evolved unique pathogenesis mechanisms to avoid host recognition and suppress host defences $[4,5]$. Bacterial effector proteins are delivered via the bacterial type III secretion system (TTSS) into the plant cell to evade recognition by the different plant surveillance systems [6]. These effectors in general contribute to host resistance or susceptibility as well as to modifying host responses. A fundamental element of the ETI in resistant plants is a localized cell collapse or a hypersensitive response (HR) at infection sites in an attempt to restrict the growth of the pathogen $[7,8]$. This is a common feature of disease resistant responses in incompatible plant-pathogen, and occasionally some non-host, interactions $[9,10]$. Some of the Xanthomonas spp. effector proteins, for instance PthA/AvrBs3, are essential to elicit citrus canker symptoms and if expressed by itself inside host cells, $p$ th $A$ is sufficient to cause symptoms of citrus canker disease [11-15]. In the meantime however, other recent studies show that other types of proteins are injected through the Xcc TTSS and do not necessarily alter the physiological and transcriptional responses to the pathogen in citrus $[8,10,16,17]$.

While certain genes involved in systemic acquired resistance (SAR) have been characterized and used as markers for studying plant defence mechanisms [18], crosstalk between signals and hormone pathways has also been proposed [19-21]. Consequently, plant resistance is correlated with the activation of a complex network of defence pathways and the response of the host plant to a microbial assault is therefore expected to result in drastic changes in the patterns of gene expression throughout the plant $[22,23]$.

Kumquats (Fortunella spp.), close relatives to citrus species, are reported to have high levels of field resistance to citrus canker [1]. Previously, we have shown a sharply contrasting phenotype in grapefruit and kumquat when both plants were challenged with a high concentration of Xccr (OD600 nm = 0.3) [24]. Grapefruit (Citrus paradisi Macf. cv. Duncan), considered to be highly susceptible to the bacterium, showed the characteristic sequence of canker lesion development. Initially lesions appeared as water soaking, followed by the development of a raised corky form; each such lesion is a reservoir of new bacterial inoculum. Bacterial exudates were visible between 10 and 21 days post-inoculation. In contrast, PCD was observed in kumquat leaves in the form of a HR 3-5 days after inoculation with the canker-causing bacterium. Only necrotic lesions were observed and the bacterial population over time was shown to have an 'avirulent' incompatible growth pattern where bacterial multiplication ceased upon the development of necrosis $[8,25]$.

New tools have been developed in recent years through advances in genomics, proteomics, and bioinformatics that have particular utility for examining pathogen: host interaction complexities [22,26-28]. The purpose of this study was to examine simultaneous changes in expression profiles for genes differentially expressed in the early stages (6-72 hpi) of citrus canker infection in kumquat, particularly those previously implicated in PCD-related responses such as HR.

\section{Results and Discussion}

In this study, identification of differentially expressed kumquat genes during its interaction with Xcc was pursued in an attempt to unravel the nature of the resistance mechanism(s) employed by the plant. Previously, kumquat suppression subtractive hybridization (SSH) cDNA libraries were constructed from Xcc-inoculated vs. mock inoculated leaves [24]. Since SSH allows differential amplification of rare target sequences due to the elimination of more abundant house-keeping cDNA transcripts found in common from both samples, the technique has the potential of uncovering pertinent cDNA sequences. Subtraction was done in both directions, forward (inoculated-mock) and reverse (mockinoculated) and the resulting cDNAs were subsequently sequenced. Preliminary screening macroarrays were used to confirm enrichment of the subtracted libraries with differentially expressed genes (data not shown).

\section{Microarray experimental design}

Kumquat microarray chip hybridization data were assessed for overall signal intensity and consistency of the expression ratio over all time points, which resulted in the exclusion of chips with inconsistent results. Figure 1 is a scatter plot showing M-values from two different biological replicate-hybridizations with Xcc-inducible targets (Cy5-labeled) and mock inoculated non-infected targets (Cy3-labeled) confirming high data consistency levels $\left(R^{2}=0.921\right)$. 


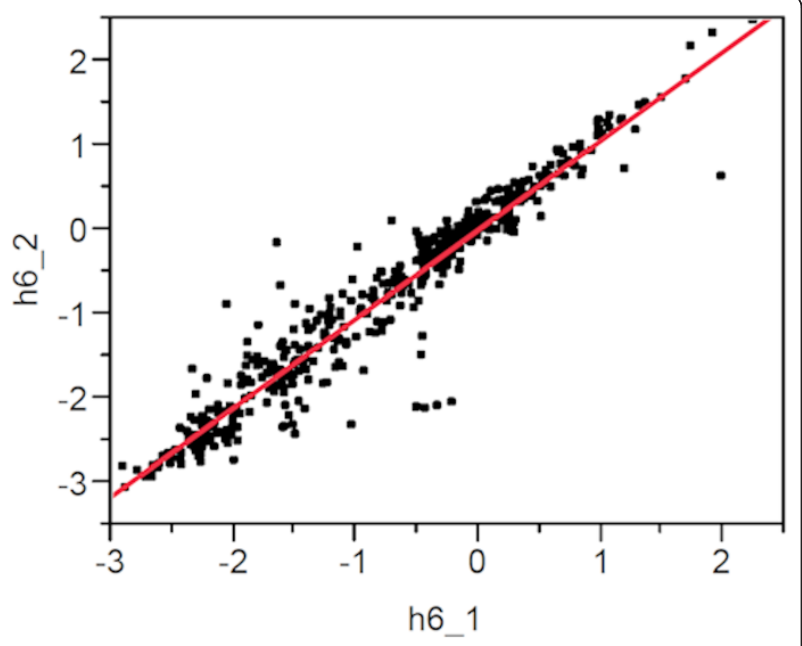

Figure 1 Scatter plot analysis of the M-values from two microarray hybridizations using RNA samples from two independent kumquat plants inoculated with $5 \times 10^{8} \mathrm{cfu} / \mathrm{ml}$ Xcc. Each spot represents the normalized hybridization signal intensity for each transcript on the microarray. RNA samples from non-inoculated and inoculated leaf tissue were labeled with Cy3 and Cy5, respectively. (h6_1): 6 hours post inoculation hybridization results from slide \# 1 hybridized to plant A-RNA samples vs. (h6_2): 6 hours post inoculation hybridization results from slide \# 2 hybridized to plant B-RNA samples.

\section{Functional annotation and an overview of global gene expression}

The B2GO program [29] was used to assign GO (Gene Ontology) terms for hits obtained through eBLAST homology searches in NCBI. A general view of the similarity of the query set with the NCBI database, the distribution of the cut off for the e-value as well as the distribution of species with similar sequences are shown in Additional files 1, 2, and 3. The GO annotation score is considered to be more intuitive than regular blast evalues since GO annotation is carried out by applying an annotation rule (AR) on the ontology terms. Additionally, query sequence descriptions are obtained by applying a language processing algorithm that extracts informative names and avoids low-content terms such as "hypothetical protein" or "expressed protein". Using Blast2Go suite default parameters, 1042 probes were provided with GO annotations (Additional file 4). Approximately $25 \%$ of the transcripts on the array do not show similarity to proteins present in public databases. Some of these could represent exclusive genes of the citrus or kumquat lineages, but a fraction of these uncharacterized sequences may possibly represent low quality or 3'UTR sequences. Similar percentages of unknown sequences have been reported in other small-scale EST projects [30-32] and therefore this pattern can be considered characteristic of this approach. Since a citrus genome sequence is now available, future studies will have a wealth of citrus genomic sequence information that can be utilized to identify kumquatspecific as well as novel citrus genes involved in diverse defence mechanisms [28].

Gene ontology analysis provided an extremely informative snapshot of the Xcc/kumquat interaction. The hierarchical structure for the gene ontology of a group of sequences can be visualized as a tree by means of directed acyclic graphs (DAG) [33]. For instance, the molecular functions of the network implicated in the kumquat response to Xcc infection is illustrated in the DAG presented in Figure 2. The graph demonstrates a tree controlled by the Seq filter that organizes the number of nodes to be displayed. Seq is the number of different sequences annotated at the child GO term. On the whole, the biological meaning for different sequences in the data set was best illustrated in terms of three GO gene categories; the biological processes (Figure 3) underlying molecular functions (Additional file 5), and the cellular compartments where proteins were localized (Additional file 6).

\section{Kumquat transcriptional changes in response to Xcc infection}

An important aspect of the data was that, for many genes, transcript abundance varied over time points, and a number of genes were only up- or down-regulated at one or two time points (Figure 4). Two approaches were used to identify patterns of gene expression. First; the ASCA-gene analysis methodology revealed that most of the total variability in the data was related to time-associated changes [34]. According to ASCA, 289 probes were selected as differentially expressed, 172 of which were at statistically significant levels (Additional file 7). Moreover, the time-associated variation could be divided into two main variability patterns. One pattern (accounting for $20 \%$ of the variation) represented genes whose expression levels changed significantly at $24 \mathrm{hpi}$ from their levels at $6 \mathrm{hpi}$ and then recovered to values similar to the starting values (or to even greater values in the opposite direction) at 72 hpi. However, the major pattern ( $80 \%$ of the time-associated variation) indicated a strong gene expression change between 6 and 24 hpi followed by preservation of expression levels at $72 \mathrm{hpi}$. This indicates that the strongest response to infection occurred at 6 to $24 \mathrm{hpi}$, and the majority of genes maintained their change for up to 3 days with a smaller percentage reverting to initial values.

The second approach, maSigPro analysis, indicated that 317 probes were differentially expressed throughout time, (adjusted $\mathrm{p}$ value $<0.05$ and $\mathrm{R}^{2}$ of the model fit $>=0.6$; Additional file 8 ). The results of both approaches were combined into 433 probes that were then filtered using more stringent conditions to provide a unique 


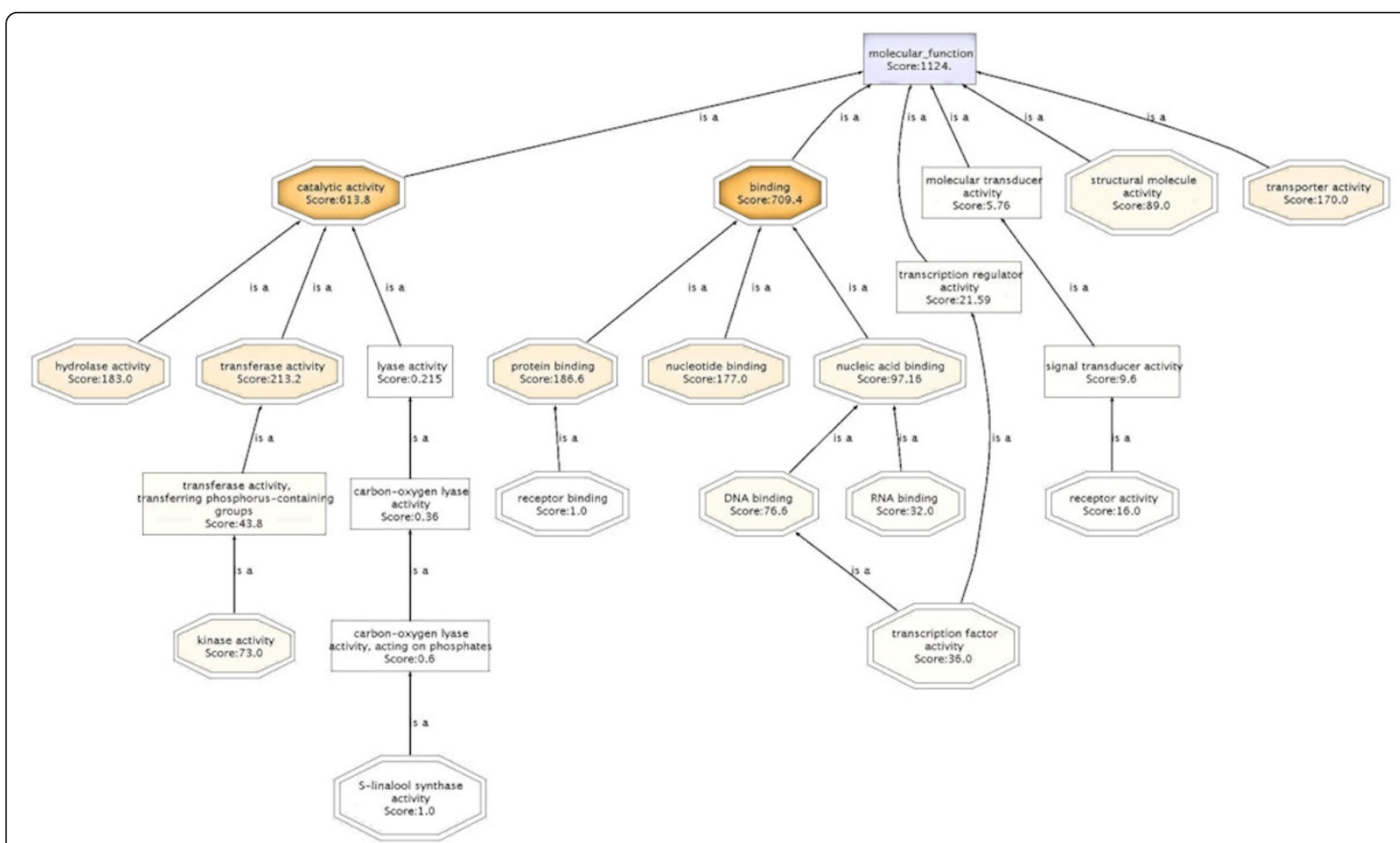

Figure 2 A Directed Acyclic Graph (DAG) visualizing the hierarchical structure of the Gene Ontology (GO) in inoculated kumquat leaves. Children that represent a more specific instance of a parent term have 'is a' relationship to the parent. The darker the color of the node the more number of Blast hits and the higher annotation score it has. All nodes contain the hit annotation scores in numbers.

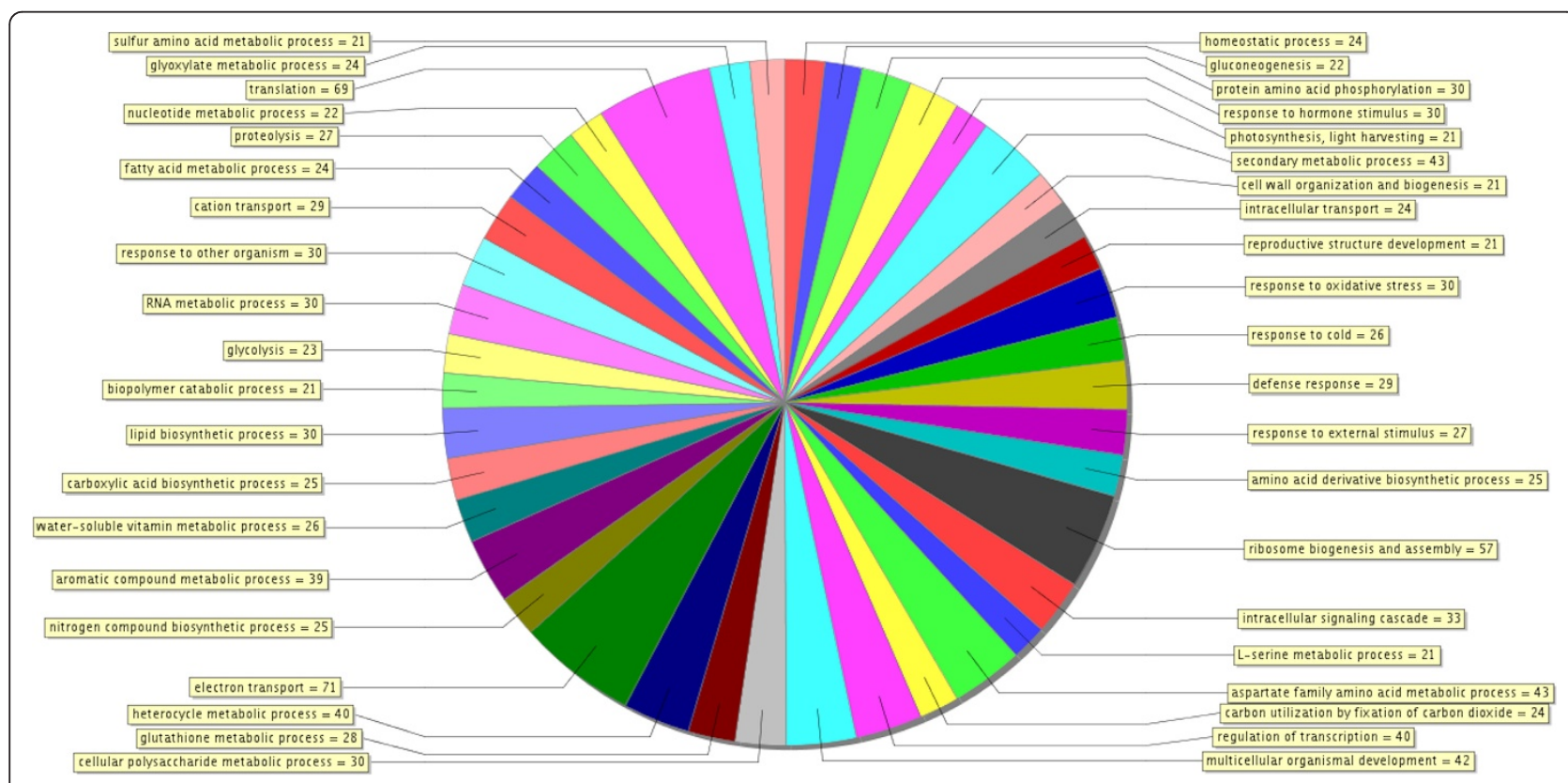

Figure $3 \mathrm{~A}$ multilevel pie chart showing the distribution of probes on the chip. Biological processes within all of the lowest nodes with the given number of sequences or score value plot jointly with an e- value cutoff (e-06). 


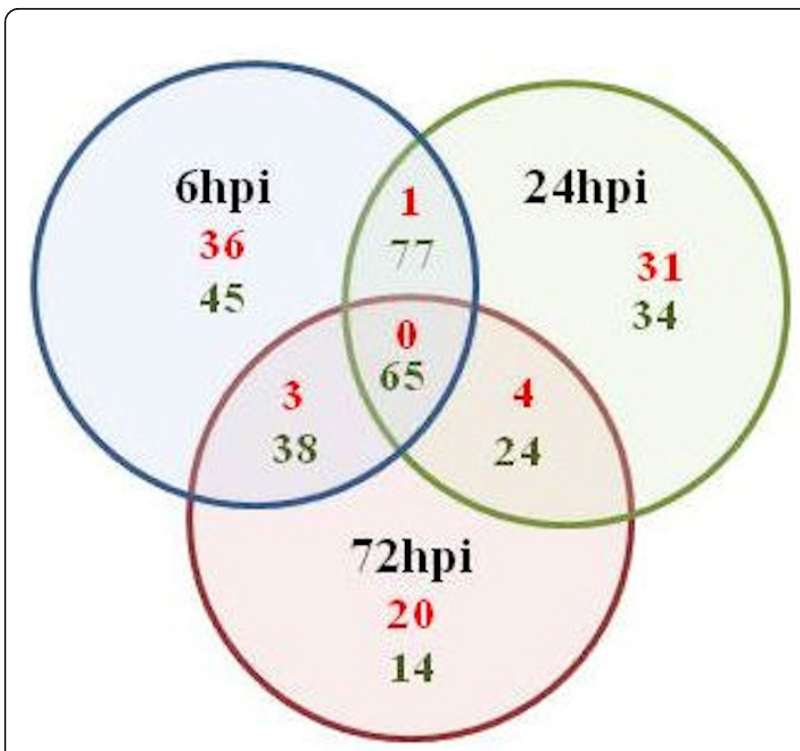

Figure 4 Venn diagram demonstrating the number of upregulated genes (numbers in red) vs the down-regulated (numbers in green) subsequent to Xcc inoculation. Results were based on the mean inductions of six experimental replicates. Genes with M-values $>0.5$ (1.5 fold) were considered up-regulated while Mvalues $<0$ were considered down-regulated.

result. The union rather than the intersection of the two approaches was taken because the two methods reveal different aspects of the data and are thus complementary. The ASCA-gene methodology focuses on shared gene expression changes to find important genes, while maSigPro treats genes independently and evaluates significant time dependent-changes. Although ASCA-gene methodology may miss some genes whose expression pattern is rare but significant, these will be captured by the gene-wise maSigPro approach. Alternatively, maSigPro can miss genes with less pronounced changes, which can be recovered by ASCA-gene if their profile is abundant within the dataset. The use of both approaches together resulted in the identification of 437 differentially expressed genes 312 of which with acceptable $\mathrm{p}$-values that could be divided into 4 clusters according to their expression patterns (Figure 5, Additional file 9). The criterion for this division is as follows. From the ASCA analysis we obtained the main patterns of variation: Cluster pattern A indicates a strong change in expression between $6 \mathrm{hpi}$ and $24 \mathrm{hpi}$, which is then maintained at time 72 hpi. Cluster B pattern is comprised of genes differentially expressed at $6 \mathrm{hpi}$ as compared to either $24 \mathrm{hpi}$ or $72 \mathrm{hpi}$. For each pattern, the correlation of the mean value of each gene at each time point with the profiles indicated by ASCA-gene was calculated; subsequently genes were divided into 4 clusters depending on whether expression levels changed in positive or negative directions. In this analysis, genes cannot be classified simply as induced or repressed, because this depends on the time points considered; for example, genes in cluster pattern $\mathrm{C}$ are repressed at 24 hpi and then induced at $72 \mathrm{hpi}$.

\section{Functional categorization of transcripts underlines key elements in kumquat response to Xcc infection}

Based on the assumption that altered gene profiles during plant-microbe interactions can be correlated with symptoms, gene ontology and annotation, we believe that Xcc represents a typical example of how the bacterial pathogen can manipulate the host systems in its favour as elucidated previously in different studies $[3,4,11,35,36]$. Information on all of the specific transcripts discussed in the subsequent paragraphs is given in Table 1. Cernadas et al. inoculated 'Pera' sweet orange with either Xcc, which causes typical canker symptoms on this citrus type, or Xanthomonas axonopodis pv. aurantifolii pathotype $\mathrm{C}$ (Xaa), which only produces symptoms on Mexican lime, followed by a detailed transcriptional analysis for the sweet orange plants [36]. Although the analyses done in that study cannot be directly compared with our study because of differences in methodology, some generalizations are noted below.

The distribution of functions within the significantly expressed genes in Xcc infected kumquats indicates that the highest number of transcripts $(\sim 30 \%)$ was associated with response to stress, electron transport, and/or oxidative stress (as shown in Figure 3), an indication of an early regulatory changes in the plant immune system by Xcc. Earlier studies, such as that of Cernadas et al., have come to the same perception [36]. Each identified cluster was subjected to functional analysis by either studying the distribution of GO terms or performing enrichment analysis to see if there were functional categories that were significantly represented. A total of 137 genes, which makes up more than $30 \%$ of the genes that were significantly expressed, were down-regulated in the interval between $6 \mathrm{hpi}$ and $24 \mathrm{hpi}$. Most of them were grouped in Clusters A and C (Figure 6). The expression levels of the genes in both of these clusters reached a minimal expression level at $24 \mathrm{hpi}$ followed by either a minor (Cluster A) or major (Cluster C) recovery by 72 hpi (Table 1). For instance, the expression of the thioredoxin $\mathrm{f}$ gene homologue (KLLFI3-F09) that belongs to cluster A reached its maximum level of expression $(+1.8$ fold) by $72 \mathrm{hpi}$ after slight decrease at 24 hpi.The lipoxygenase gene homologue (KSLFII1-F07) that belongs to cluster $C$ was 1.5 fold down-regulated at 6 hpi followed by a 3 fold increase in expression when compared to the its expression level at 6 hpi sample. Genes in Cluster $\mathrm{A}$ and $\mathrm{C}$ were frequently related to oxidative stress 
response. Most of the activity for genes in these clusters is located in the mitochondria, the cell membrane and the chloroplast (Figure 6). Cluster B was the largest cluster and included 235 genes with up-regulated expression levels between $6 \mathrm{hpi}$ to $24 \mathrm{hpi}$ followed by sustained expression until 72 hpi (Figure 5, Figure 7A). Cluster D contained 61 members that had a low steady expression up to $24 \mathrm{hpi}$, and were subsequently upregulated (Figure 5, Figure 7B). This cluster includes genes, such as the glycosyltransferase-like gene (KSLFI7-F12), that mediate the transfer of glycosyl residues from activated nucleotide sugars to acceptor molecules (aglycones), a key mechanism in determining the diversity, activity and chemical complexity of plant natural products. In plants, UGTs (uridine diphosphate sugar glycosyl transferases) generally use UDP-glucose and occasionally UDP-xylose for glucosylation of phenylpropanoid aglycones. Albrecht and Bowman [37] proposed using UGTs and other glycosyltransferases as prospective genetic engineering candidates due to their important role in resistance and tolerance to citrus tristeza virus (CTV) as well as citrus huanglongbing (HLB) in trifoliate oranges (Poncirus trifoliata L. Raf.). Phenolics are mainly synthesized in plants via the phenylpropanoid pathway and are incorporated into many important compounds including plant hormones, secondary metabolites involved in stress, defence responses, and xenobiotics such as herbicides [38]. In addition,
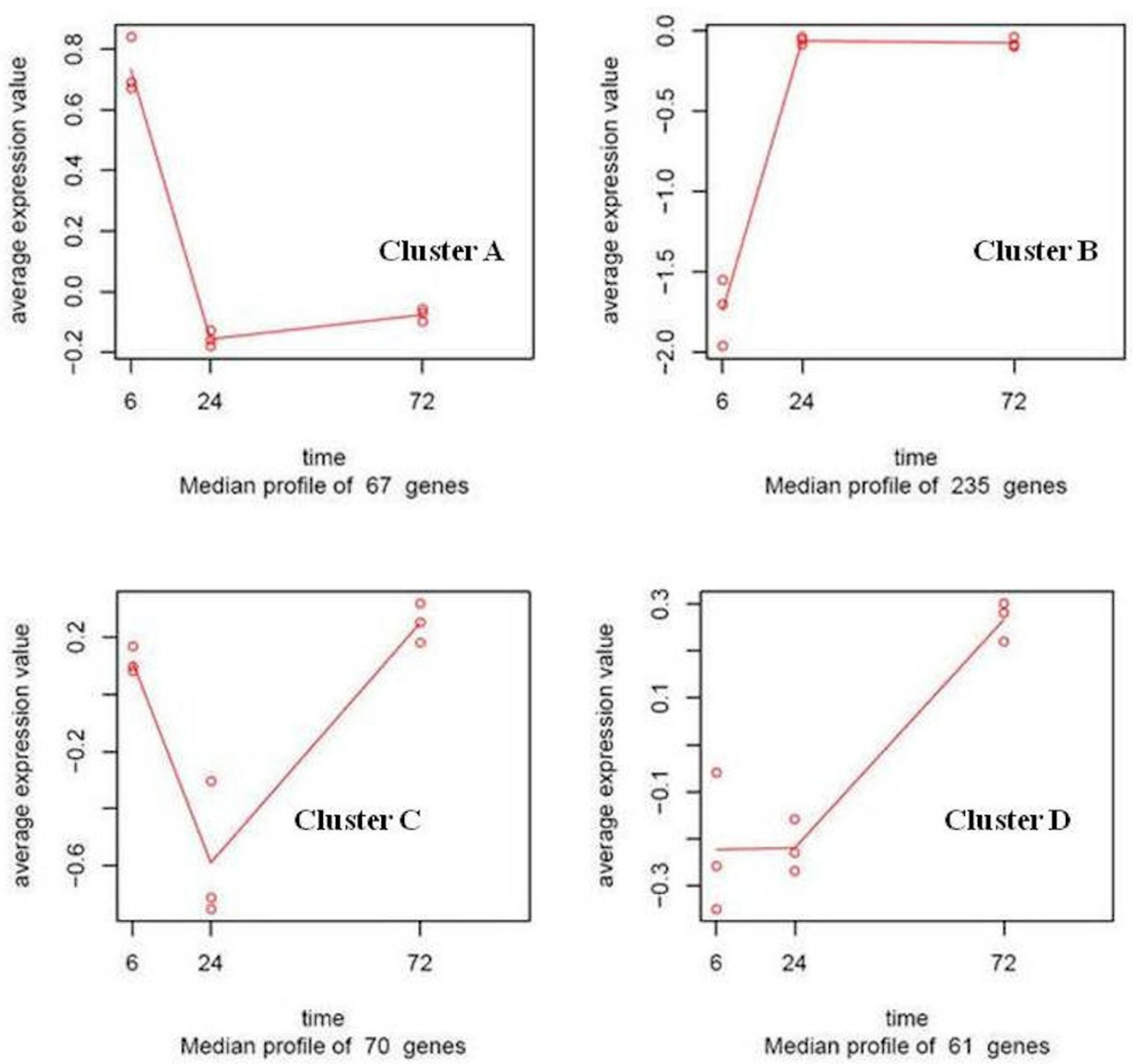

Figure $\mathbf{5}$ Cluster patterns. The overall average gene expression profiles for genes from different functional clusters at each time-point. 
phenylpropanoid pathway intermediates, for example pcoumaric acid, caffeic acid, ferulic acid and sinapic acid, and pathway derivatives, including flavonoid aglycones and glycosides, exhibit antimicrobial activity $[39,40]$.

\section{Kumquat transcriptional changes in response to Xcc infection \\ ROS vs ROS scavenging}

In order to maintain homeostasis and overcome the damaging effects of ROS (reactive oxygen species), a balance between SODs (superoxide dismutase) and the different $\mathrm{H}_{2} \mathrm{O}_{2}$-scavenging enzymes is considered to be critical in determining the levels of $\mathrm{O}_{2}{ }^{-}$and $\mathrm{H}_{2} \mathrm{O}_{2}$ in plant cells $[41,42]$. Accordingly, there is a constant interplay between the antioxidant state and processes generating ROS. ROS are produced in chloroplasts, peroxisomes, and mitochondria in response to biotic as well as abiotic stresses [43,44]. Accordingly, the expression of different enzymes that produce ROS were evidently stringently controlled and coordinated during the kumquat/Xcc interaction. For instance, while formate dehydrogenase (FDH; KLLRI2-G05), a mitochondrial NAD dependent enzyme, was 1.5 fold upregulated by 6 hpi, amine oxidase (KSLFI3-G05) that contributes to the synthesis of $\mathrm{H}_{2} \mathrm{O}_{2}$ and secondary metabolites was downregulated by 1.5 and 1.6 fold at 6 and 24 hpi respectively in response to Xcc challenge (Table 1). Concurrently, Xcc-inoculated kumquat plants overexpressed genes related to ROS scavenging to restrict damage to the inoculated parts of the plant, in this case the leaves. For instance, CuZnSOD (KLLF13-A03) expression in kumquats was increased $\sim 1.5$ fold at $6 \mathrm{hpi}$ and was stabilized at $24 \mathrm{hpi}$ and $72 \mathrm{dpi}$ (Table 1). The same phenomenon was observed previously in tomato infected with Botrytis cinerea, a sign of increased ROS production by the host as part of the defence response to infection [45]. Furthermore, while the expression of some of the genes linked to protease inhibitors and endopeptidase activities such as protease inhibitor homologue (KLLFI2-D02) was suppressed by the bacteria, other serine-type endopeptidase inhibitors such as an ATP-dependent ion protease (KSLFIV1-H05) was $>2$ fold up-regulated as early as 6 hpi subsequent to Xcc inoculation. In the same context, the redox coupling ascorbate-glutathione cycle, known to be responsible for peroxide detoxification [46], was repressed by $6 \mathrm{hpi}$ in the kumquat dataset; examples include dehydroascorbate reductase (KSLRI1-F02) and glutathione peroxidase (KLLFII3-G07). Ascorbate and glutathione are non-enzymatic antioxidant molecules that have a role in other cycles, including those that synthesize and in some cases modulate flavonoids, alkaloids, phenolic compounds, $\alpha$-tocopherol and carotenoids, all of which contribute in scavenging ROS [47]. Dehydroascorbate reductase activity is indispensible when the ascorbate peroxidase (APX) levels are higher than normal under certain conditions to ensure preservation of the reduced form of ascorbate. Both proteins in addition to certain types of trypsin inhibitors might also catalyze a plant response [48]. A similar study to investigate the Xanthomonas-grapefruit compatible interaction might present a platform to compare gene expression profiles of some genes of interest in both plants.

Accumulating evidence indicates that protein ubiquitination and degradation, last steps in protein turnover, are involved in plant defence responses. A number of recent studies have investigated a possible role of $U$ box E3 ubiquitin ligases in PTI (PAMPS-triggered immunity), ETI (effector-triggered immunity), as well as plant cell death and defence $[49,50]$. In the present study, 6 ubiquitination pathway-related genes, for example ubiquitin-conjugating enzyme ucb7 (CSL1A02), were isolated in the kumquat forward subtracted libraries; more investigation of their expression levels after infection will follow. Other induced genes that are involved in the proteolysis process are present in clusters A, B and C.

\section{Genes involved in photosynthesis}

A distinct down-regulation in the expression of ribulose1,5-bisphosphate carboxylase/oxygenase at $6 \mathrm{hpi}$, followed by an increase in expression that reaches maximum expression at $24 \mathrm{hpi}$, was observed in the microarray dataset (Rubisco small and large subunits; for example KLLFIII3-G09 and KSLRII2-F01) (Table 1). Rubisco, the most abundant protein in leaves, is the main source of energy production in plant cells. A decrease in photosynthesis was previously shown in Arabidopsis leaves as early as $3 \mathrm{~h}$ after challenge with the $P$. syringae avirulent strain, while after $48 \mathrm{~h}$ the rate of photosynthesis was lower with the virulent strain [51]. Most of the photosynthetic machinery in challenged kumquat leaves was repressed at $6 \mathrm{hpi}$, including chlorophyll A/B binding protein (KLLFIII3-A06 and KLLFIII3-E08). Three photosynthesis-related genes were differentially down-regulated during the first 24 hours. In Pto-mediated resistance, 30 photosynthesis-related genes and 12 genes encoding chloroplast-associated proteins were suppressed [52]. These results show that plants reduce photosynthetic potential to induce HR following pathogen attack. Further, Quirino et al. [53] suggested that HR and senescence are two programs that involve biochemical similarities as well as an overlap. The research reinforced the idea of a connection between defence response and senescence. Evidently, the down-regulation of genes involved in photosynthesis during the Xcc/kumquat interaction represents a cost for the plant fitness where energy resources were redirected to defence response. 
Table 1 Functional categorization of cDNAs identified from microarray analysis.

\begin{tabular}{|c|c|c|c|c|c|c|}
\hline \multirow[t]{2}{*}{ Putative Function } & \multirow[t]{2}{*}{ Cluster } & \multirow[t]{2}{*}{ P-Value } & \multirow[t]{2}{*}{ ID } & \multicolumn{3}{|c|}{ M-Value } \\
\hline & & & & $6 \mathrm{hpi}$ & $24 \mathrm{hpi}$ & $72 \mathrm{hpi}$ \\
\hline \multicolumn{7}{|c|}{ OXIDATIVE BURST/STRESS, APOPTOSIS } \\
\hline *Thioredoxin $\mathrm{f}$ & A & 0.093 & KLLFI3-F09 & +0.093 & +0.037 & +0.913 \\
\hline *Peroxidase & C & 0.046 & KLLRI2-F09 & -2.370 & -0.280 & -0.380 \\
\hline${ }^{*}$ Class III peroxidase & B & 0.018 & KSLF11-H03 & +1.643 & +0.323 & +1.053 \\
\hline $\begin{array}{l}\text { Glycosyl transferase-like } \\
\text { protein }\end{array}$ & D & 0.004 & KSLFI7-F12 & -2.237 & +0.103 & -0.243 \\
\hline${ }^{*}$ Glutathione peroxidase & D & 0.024 & KSLFI1-B02 & -2.143 & -0.027 & -0.287 \\
\hline *Formate dehydrogenase & B & 0.041 & KLLRI2-G05 & +0.930 & -0.447 & +0.173 \\
\hline${ }^{*}$ CuZn-superoxide dismutase & B & 0.035 & KLLFI3-A03 & +0.523 & -0.267 & -0.086 \\
\hline *Protease inhibitor & B & 0.015 & KLLFI2-D02 & -1.987 & +0.653 & +0.510 \\
\hline *Ion protease homologue & D & 0.074 & KSLFIV1-H05 & +1.220 & -0.607 & +0.240 \\
\hline $\begin{array}{l}\text { *Dehydroascorbate } \\
\text { reductase }\end{array}$ & C & 0.012 & KSLR1-F02 & -2.033 & -0.040 & -0.223 \\
\hline${ }^{*}$ Glutathione peroxidase & C & 0.021 & KLLFII3-G07 & 0.267 & -0.237 & -0.247 \\
\hline *Ubiquitin-conjugating enzyme ubc7 & B & 0.015 & CSL1-A02 & -0.163 & -0.390 & +0.320 \\
\hline Catalase (EC 1.11.1.6)CAT-2 & C & 0.041 & KLLFI1-F11 & -1.343 & -0.207 & -0.253 \\
\hline *Amine oxidase & A & 0.035 & KSLFI3-G05 & -0.553 & -0.720 & +0.493 \\
\hline Hydroperoxide lyase & B & 0.012 & CSL2F2-A01 & -2.963 & -0.427 & -0.167 \\
\hline Benzoic acid salicylic acid methyltransferase & C & 0.034 & KLLRI2-C03 & +0.103 & -0.233 & -0.263 \\
\hline $\begin{array}{l}\text { *1-aminocyclopropane-1- } \\
\text { carboxylate oxidase }\end{array}$ & B & 0.008 & KSLFI7-H12 & -1.993 & +0.183 & -0.310 \\
\hline \multicolumn{7}{|l|}{ PHOTOSYNTHESIS } \\
\hline Chlorophyll ab binding protein & B & 0.006 & KLLFIII3-A06 & -2.057 & +0.217 & +0.563 \\
\hline Chloroplast photosystemll 22kda & B & 0.15 & KLLFIII3-E08 & -0.717 & +0.433 & -0.050 \\
\hline \multicolumn{7}{|l|}{ DEFENCE } \\
\hline *Pathogenesis-related protein $1 \mathrm{a}$ & A & 0.054 & KSLFI3-H10 & -1.803 & -0.077 & -0.407 \\
\hline *SABP2 & B & 0.008 & KLLRI2-G01 & +0.787 & -0.093 & -0.317 \\
\hline *Beta-1,3-glucanase & B & 0.024 & KSLFII1-C07 & -1.91 & -0.760 & -0.167 \\
\hline Phenylalanine-ammonia lyase & D & 0.016 & KSLFI4-F04 & -2.58 & -0.013 & -0.147 \\
\hline Pathogenesis-related protein $4-1$ & A & 0.032 & KLLFII2-G01 & +0.07 & -0.210 & -0.353 \\
\hline${ }^{*}$ Class IV chitinase & C & 0.626 & KLLRI2-D05 & +0.01 & -0.3 & -0.28 \\
\hline *NDR1 homologue & C & 0.132 & KLLFII2-E03 & -0.91 & -0.74 & -0.04 \\
\hline *Trypsin inhibitor & A & 0.011 & KSLFIII1-H12 & -0.40 & +1.05 & +0.303 \\
\hline *Trypsin inhibitor & B & 0.008 & KLLFIII3-F03 & -3.20 & +0.197 & -0.490 \\
\hline *HSR203J-like protein & C & 0.003 & KSLFI3-C10 & +0.073 & -0.09 & -0.303 \\
\hline $\begin{array}{l}\text { *DND1 [Arabidopsis } \\
\text { thaliana] }\end{array}$ & D & 0.074 & KLLRI2-B05 & -0.203 & -0.580 & +0.310 \\
\hline *Bax inhibitor-1 & $\mathrm{C}$ & 0.01 & KLLFIII2-E02 & +0.233 & +0.083 & +0.06 \\
\hline $\begin{array}{l}\text { *Latex-abundant (caspase } \\
\text {-like) }\end{array}$ & B & 0.090 & KLLRI2-A12 & +0.230 & +0.173 & +0.09 \\
\hline *Zinc finger protein & B & 0.017 & KSLFI6-C10 & +2.387 & +0.000 & +0.663 \\
\hline
\end{tabular}

M-value is the base two logarithm of the ratio between the background-subtracted foreground intensity measured in the red and the green channels.

These ESTs were identified as having a cy 5 cy3 ratio $> \pm 1.5$ for four out of six spots on the microarrays.

- Putative function determined with the Gene ontology sequence description

- Cluster: The cluster to which the putative gene belongs according to Blast2 GO functional analysis.

- P-value associated to the statistical analysis for differential expression adjusted for multiple comparisons.

- ID: Assigned at selection.

- M-Value: A metric for comparing a gene's mRNA-expression level between two distinct experimental conditions; in this case mock inoculated vs Xcc inoculated.

- (-) means down-regulated where M-value $<0$ while (+) is up-regulated where M-value $>0$

Table 1. includes (*) genes that are discussed in the text.

While other sequences that might not be mentioned in the text but show interesting gene expression profiles. 


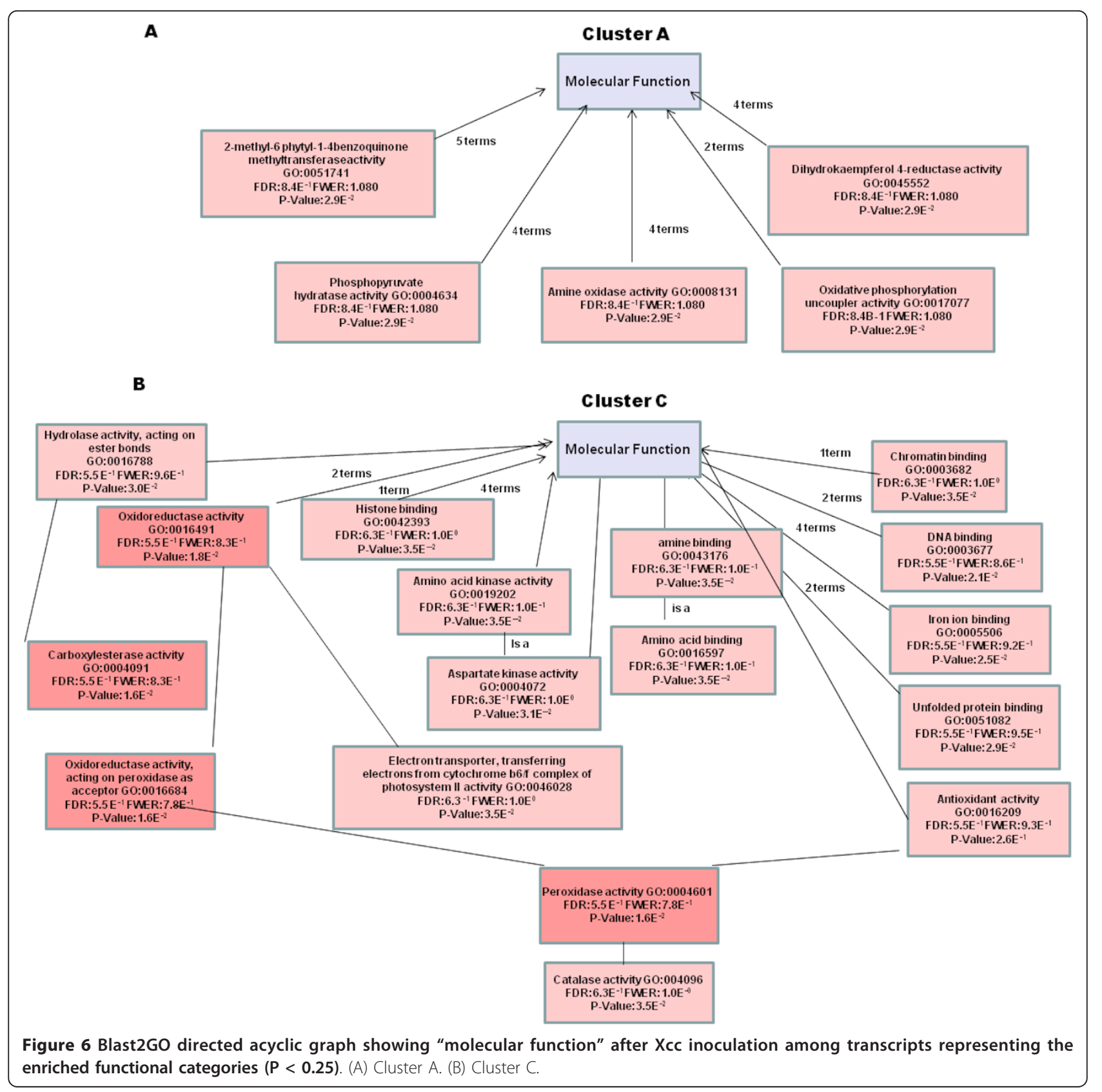

\section{Cell wall remodelling}

Xcc inoculation of kumquat was followed by the downregulation of various genes related to cell wall remodeling and rapid expansion such as endoglucanases. The expression level of a kumquat homologue of this wall loosening protein (KLLFI2-C10) was insignificant. On the other hand, genes related to cell wall reorganization, for example xyloglucan endotransglycosylase/hydrolase (XET,- an enzyme involved in cell wall elongation and restructuring), were significantly up-regulated by $24 \mathrm{hpi}$ (KSLFIII1-H08). In 'Pera' sweet orange, a major difference in the response to inoculation of the two bacterial strains was that Xcc strongly upregulated several cell wall remodelling enzymes, while Xaa upregulated genes related to endoglucanase inhitors and lignin biosynthesis. A phenomenon that we observed in kumquat plants is the development of a few minute necrotic flecks on the leaves when inoculated with low concentrations of the bacterium (Xcc). Neither leaf abscission nor water soaked lesions were observed on the leaves later under our conditions. It is also worth mentioning that although Cernadas et al. used a relatively high 


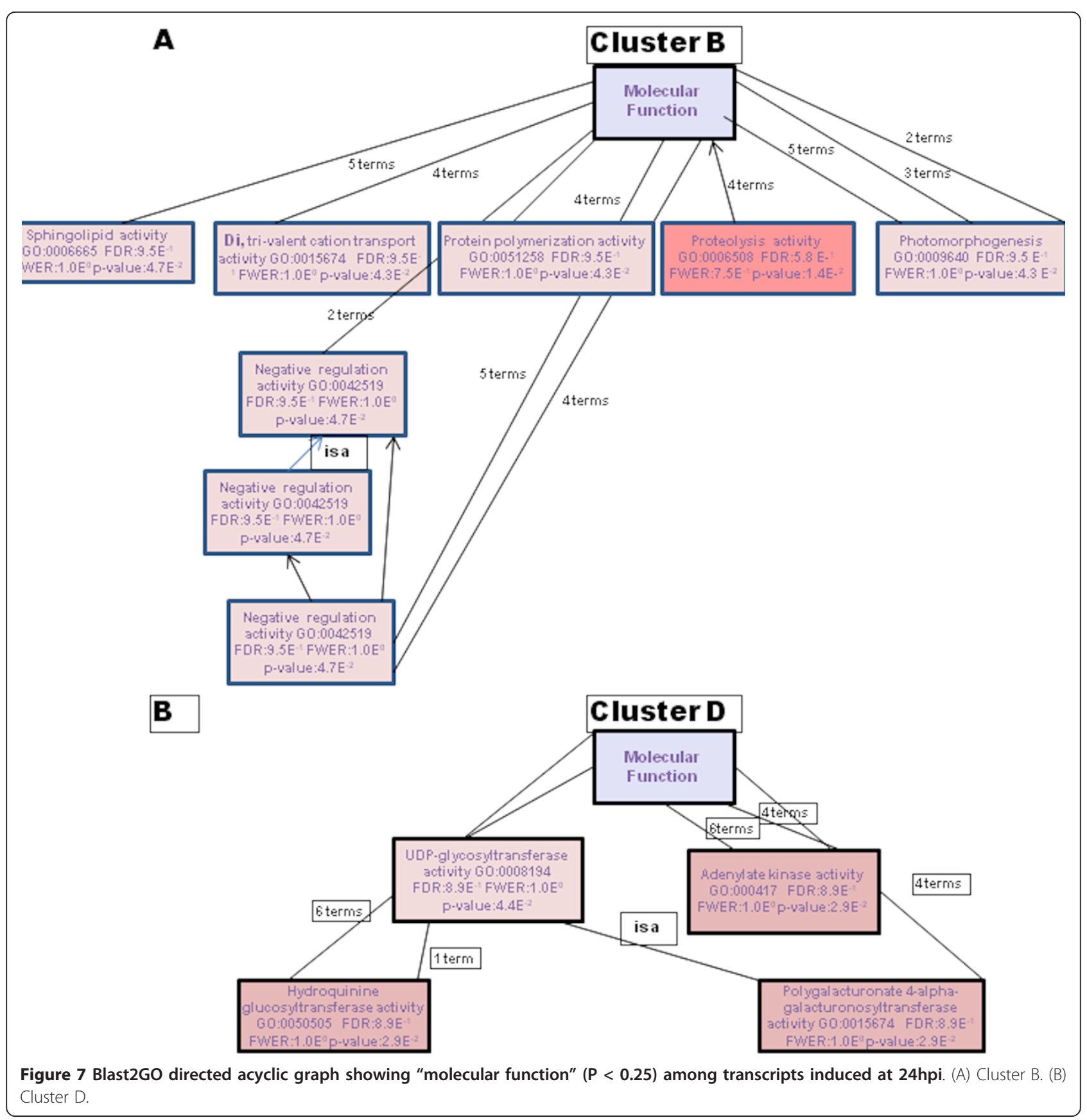

concentration of Xaa (OD600 nm $=0.6$, double what we used for Xcc with kumquat) only pustles were recorded in sweet orange inoculated with Xaa that were not followed by necrosis [24]. Using light microscopy, we have previously shown mesophyl collapse in kumquat leaves which was followed by leaf abscission $72 \mathrm{hrs}$ post inoculation with Xcc. Alternatively, grapefruit mesophyl cells from inoculated leaves showed enlargement (hypertrophy) and division (hyperplasia) followed by raised circular lesions that became raised and developed into white or yellow spongy pustules. These pustules then darkened and thickened into brown corky canker lesions [24]. Pustule formation and hypertrophy were linked previously to the PthA effector in Nicotiana benthamiana [35]. Alternatively, accumulation of the tomato XTH (xyloglucan endotransglucosylase/hydrolase LeXTH1) protein 6 hours after attachment of the parasite has provided evidence for a role of $X T H$ in defence reactions associated with the incompatible tomatoCuscuta interaction as was presented in Albert et al. [54]. 
Table 2 qRT-PCR analysis of genes expressed in response to Xcc inoculation a $\left(5 \times 10^{8} \mathrm{cfu} / \mathrm{ml}\right)$ concentration of the Miami strain X04-59.

\begin{tabular}{|c|c|c|c|c|c|c|c|c|c|}
\hline \multirow[t]{2}{*}{ Gene ID } & \multirow[t]{2}{*}{ Function } & \multicolumn{4}{|c|}{$\begin{array}{c}\text { Microarray } \\
\text { (Fold Change) }\end{array}$} & \multicolumn{4}{|c|}{$\begin{array}{l}\text { Real-time PCR } \\
\text { (Fold Change) }\end{array}$} \\
\hline & & $6 \mathrm{~h}$ & $24 \mathrm{~h}$ & $72 \mathrm{~h}$ & $0 \mathrm{t}$ & $6 \mathrm{~h}$ & $24 \mathrm{~h}$ & $72 \mathrm{~h}$ & $120 \mathrm{~h}$ \\
\hline KLLFII2-C05 & Basic leucine zipper transcription factor & -1.04 & +1.06 & -1.21 & 1 & -0.53 & +1.13 & +1.57 & +0.26 \\
\hline KLLRI2-D05 & Class I chitinase (CHI1) & +1.01 & -1.23 & -1.21 & 1 & +2.9 & -0.16 & 9.21 & -4.53 \\
\hline CSL1-D05 & A disease resistance leucine-rich repeat protein & +1.06 & +2.04 & +1.08 & 1 & +3.09 & +7.73 & +1.66 & +0.19 \\
\hline KLLRI2-H10 & Receptor-like serine threonine kinase & +1.62 & -1.02 & -1.19 & 1 & +2.65 & +0.51 & +0.53 & +0.47 \\
\hline KLLFII1-B11 & A putative beta-galactosidase BG1 & -1.13 & -1.24 & +1.01 & 1 & -1.24 & -0.10 & +0.91 & +0.19 \\
\hline CSL2-A02 & $\begin{array}{l}\text { A mitogen-activated } \\
\text { protein kinase } 3\end{array}$ & +1.02 & -1.11 & +1.16 & 1 & +5.66 & -14.1 & +1.22 & +0.58 \\
\hline
\end{tabular}

\section{Resistance genes and related proteins}

Most of the differentially expressed genes in the kumquat/Xcc interaction have also been identified in plantinsect interactions [55], non-host resistance [56] and Rgene mediated resistance [52], suggesting a high level of convergence between different types of resistance mechanisms. The expression levels of some homologues to the PR3 (endochitinase) (KFII1-B11) and B-galactosidase (BG1) (KRI2-D05) genes were found to be modestly activated; 2 and 1 fold up-regulated respectively 6 hpi, although both genes were down-regulated by $24 \mathrm{hpi}$ as shown by the microarray and the qRT-PCR (quantitative real-time PCR) data (Table 2, Additional File 10). Chitinase expression is a plant defence strategy typically used against wall components of fungi and insects [57]. According to the qRT-PCR, the kumquat chitinase gene was $>2$-fold up-regulated by $6 \mathrm{hpi}$, after which it was suppressed at $24 \mathrm{hpi}$, and then its expression increased. Other studies have also reported the induction of chitinases in response to bacterial pathogens but their function is not well known [58].

Interestingly, the expression levels of the kumquat PR1 (Pathogenesis -related gene1) gene homologue, normally a marker of salicylic acid-induced systemic acquired resistance (SAR) that is usually up-regulated after pathogen infections, was lower in the infected samples as early as 6 hpi compared to control mock inoculated samples (KLLFII2-A04) (according to the microarray results and non-published data). The region upstream of the PR1 promoter, W-box sequences, was shown previously to act as a negative cis-acting element in the expression of defence related genes [59]. This implies a different basal defence response and SAR regulation mechanism from that of Arabidopsis and other dicotyledonous plants in kumquat after Xcc infection. PR genes that were identified in citrus vary in their responses to different pathogens as shown in this study and others where variation in expression levels of different members of the PR gene family was dependent on the nature of different elicitors [60-62]. The biological activity of a large majority of PR genes in plants during biotic stress is yet to be revealed. More interestingly, according to the microarray results, expression levels of a number of homologues to other defence related genes such as the NDR1 gene (KLLFII2-E03) were also repressed 24 hpi after Xcc infection.

LRR proteins are known to be a part of the early signal transduction cascade involved in the recognition of pathogen Avr products [63]. Sequences for a number of homologues known to be part of different hormonal defence pathways (for instance transcription factors, receptor like and receptor-like kinases) were found to be differentially expressed in kumquat after Xcc inoculation.

\section{Key molecular features of kumquat $P C D$}

A number of genes homologous to known resistant response-specific genes were expressed in the kumquat transcriptome concurrently following Xcc inoculation, listed and discussed below:

(i) KSLFI3-C10 is homologous to hsr203J , a carboxylesterase (CXE) gene implicated previously in the incompatible interactions between tobacco and the bacterial pathogen Ralstonia solanacearum. Its promoter is highly, rapidly, and specifically activated in response to HR inducing bacterial inoculation, does not respond to various stress conditions, and is strongly dependent on hrp (hypersensitive response and pathogenicity) genes of the pathogenic bacterium [64]. It has been proposed that its expression should be a useful marker for programmed cell death occurring in response to diverse pathogens.

(ii) KLLRI2-B05 shares homology with DND1 (DEFENCE NO DEATH 1), which encodes a cyclic nucleotide-gated ion channel that allows passage of $\mathrm{Ca} 2$ ,$+ \mathrm{K}+$ and other cations. The Arabidopsis thaliana dnd1 mutant failed to produce HR cell death in response to an avirulent pathogen infection [65].

(iii) During programmed cell death or apoptosis cytochrome $\mathrm{c}$ is released to the cytoplasm from the intermembrane space of the mitochondrion [66,67]. Once in 
the cytoplasm, it activates caspases (cysteine aspartatespecific proteases), killer proteins that dismantle the cell [68]. Two key proteins known to be core components of the apoptic machinery in animals, caspase and Bax-Inhibitor1 gene homologues, were identified in our dataset. According to our data, a homologue that has caspase activity KLLRI2_A12 was slightly up-regulated by 6 hpi in kumquat challenged leaves. Bax is a member of the Bcl2 family that plays a regulatory role preventing apoptosis by inhibiting adapters needed for the activation of caspases [54]. A kumquat homologue of the Bax-Inhibitor1 gene (KLLFIII2-E06) was shown to be slightly up regulated $6 \mathrm{hpi}$ in response to Xcc challenge as was previously shown with Arabidopsis thaliana Bax Inhibitor-1 (AtBI-1), isolated during a differential screen of plants challenged with the phytopathogen Pseudomonas syringae [69]. In the same context, Bax inhibitor has been shown to trigger cytochrome c release from mitochondria both in vitro and in vivo in animals.

(iv) Endopeptidase inhibitors are often part of an inducible, jasmonic acid associated defence pathway that accumulates upon wounding, pathogen, or herbivore damage in leaves [26]. The antagonistic interaction between proteases and endopeptidase inhibitors is considered to be a cell death control mechanism [70]. Li et al., 2008 demonstrated that a serine protease (Kunitz trypsin) inhibitor (KTI1) of Arabidopsis is involved in modulating PCD in plant-pathogen interactions [71]. RNAi silencing of the AtKTI1 gene resulted in enhanced lesion development after infiltration of leaf tissue with the PCD-eliciting fungal toxin fumonisin B1 (FB1) or the avirulent bacterial pathogen Pseudomonas syringae pv tomato DC3000 carrying avrB (Pst avrB). Trypsin inhibitor (KSLFIII1-H12 and KLLFIII3-F03) and a miraculin serine type endopeptidase inhibitor (FI2-A05) sequences were found in original early subtraction libraries representing transcripts expressed during early infection (30 min.pi-24 hpi). While KLLFIII3-F03 (trypsin homologue) gene expression was significantly suppressed $6 \mathrm{hpi}$, the expression of KSLIII1-H12 was slightly suppressed and then 2 fold upregulated 24 hpi. Further analysis should be done to study the difference between the mechanism(s) of action of these two genes.

\section{Suppression of defence responses}

A very evident down-regulation of a considerable number of genes was recorded by 6 hpi which may be caused by defence suppression imposed by Xcc effectors (Clusters A and C; Figure 6A and 6B). It has been shown previously that Xcc exploits the Type III secretion system (T3SS) to inject different effector proteins into citrus plants in order to avoid host recognition and subsequently MAMPS/PAMP-triggered immunity. The bacterial effector proteins suppress plant defences including basal defence, gene-for-gene resistance, and nonhost resistance. There was no accumulation of any SAR gene transcripts including PR1, a marker for enhanced defence; in addition some other key elements in the SA defence pathway were suppressed. On the other hand, the S-adenosyl-1-methionine:benzoic acid salicylic acid carboxyl methyltransferase gene (KLLRI2C03) was at least 1-fold upregulated in kumquat leaves by $6 \mathrm{hpi}$ in response to Xcc inoculation; the gene is known to play a role in plant defence responses [72]. In addition, the SA-binding protein 2 (SABP2 KLLRI2G01), a lipase protein that belongs to the hydrolase super family, was found to be up-regulated at 6 hpi by at least 2 fold; the gene was previously found to be required for the plant immune response in tobacco [73].

\section{Realtime Quantitative Polymerase Chain Reaction}

\section{Validation}

Validation of the presented microarray dataset was carried out using TaqMan gene expression assay for a number of homologues on the array. Genes that were implicated in plant defence including basic leucine zipper transcription factor (KLLFII2-C05), a putative chitinase protein (CHI1)(KLLRI2-D05), a putative disease resistance leucine rich protein (CSL1-D05), a receptor like protein kinase (KLLRI2-H10), a beta galactosidase like protein (KLLFII1-B11) and a putative mitogen-activated protein (CSL2-A02) were selected for validation using q RT-PCR. As summarized in Table 2 and Additional file 10, the qRT-PCR data correlated with the microarray results confirming the up-or down-regulation of all analyzed genes although as expected the qRT-PCR was more sensitive.

\section{Conclusions}

In this study, a $F$. margarita custom microarray representing 1024 unigenes was used to study the response to inoculation with $X$. axonopodis pv. citri. A very distinct though delayed HR was observed in Xcc-inoculated kumquat plants where initially the bacterium grew exponentially, followed by a sudden leaf tissue collapse (necrosis with no canker lesions) 2-5 days after inoculation [24]. A comparable delayed HR was observed in tomato resistance response to race $\mathrm{T} 3$ mediated by AvrXv3 effector and RxvT3 R protein [74]. The current kumquat analysis allowed simultaneous investigation of the expression of more than one group of genes known to be linked to more than one biological process and cellular compartment in relation to the HR caused by Xcc infection. A large number of genes were found to be differentially expressed after infection. Most of the genes involved in defence mechanisms in kumquat appear to be associated with the phenomena that precede the HR including oxidative burst, protein degradation, and regulation of photosynthesis as well as the production of ROS that is associated with the oxidative 
burst. One very distinct observation was that some of the defence genes such as PR1 and NDR1 were downregulated in kumquats in response to Xcc inoculation as early as $6 \mathrm{hpi}$, a phenomenon currently under further examination. What clearly appears to be a resistant response and a drastic decrease in the bacterial population, in addition to the activation of genes involved in ROS production as well as and programmed cell death, seems to be a common mechanism that is pursued by more than one citrus bacterial pathogen with no associated-resistance genes yet identified $[24,36]$. Future work will compare differences in gene response in both resistant and susceptible citrus types.

\section{Methods}

\section{Plant material and inoculation with bacteria}

Fortunella margarita (Lour.) Swingle (Nagami kumquat) plants were used in all of the experiments described in this study. Plants were approximately 2 years old at the time of the experiment and were maintained in the quarantine greenhouse facility at the Division of Plant Industry, Florida Department of Agriculture (Gainesville, FL, USA) under controlled conditions. Leaves from a set of six kumquat plants were infiltrated with bacterial cultures according to Lund et al. [75]. The bacterial strain used was Xanthomonas citri subsp. citri A; Miami X0459 (Xcc). The inoculum was adjusted to $5 \times 10^{8} \mathrm{cfu} / \mathrm{ml}$. A similar set of plants was mock-inoculated using sterile tap water as controls. Leaves from the two sets of plants were used in subsequent experiments.

\section{Microarray platform}

The kumquat microarray chip was developed and printed at the University of Florida (Gainesville, FL, USA). The array included ESTs chosen from 4 previously constructed Nagami kumquat forward and reverse leaf subtraction cDNA libraries. The cDNA libraries were constructed using RNA extracted from leaf tissue collected at different intervals post inoculation with Xcc (see below) and pooled into early and late library sets to capture a wide spectrum of differentially expressed transcripts [24]. Random DNA sequencing was performed from 5'and 3' ends of randomly selected clones using universal primers, generating sequence information from 2788 and 1655 clones from the early and late leaf subtraction libraries respectively.

The initial dataset was reduced to a total of 2304 transcripts that were selected according to sequence alignment similarities with proteins in the Genbank database. Sequences were selected based on quality and length. The dataset included 2254 kumquat ESTs comprising 738 contigs and 1516 singletons, in addition to 50 cDNA control elements. Each probe was printed in 3 locations on the array using the Omnigrid Microarrayer (Gene Machines, San Carlos, CA, USA) so that all clones had 3 technical replicates on each slide, generating a total of 6912 spots. Post-printing slide processing was performed as described in Heller et al. (1997) [76] with some modifications. In brief, a combination of sequential baking and UV crosslinking was implemented where slides were baked for $80 \mathrm{~min}$ at $80^{\circ} \mathrm{C}$ in a drying oven without vacuum. The slides were then washed twice in $0.1 \%$ SDS for 5 minutes each to remove any unbound DNA.

\section{Experimental plan}

To identify genes that are considered to be differentially expressed in kumquat, a time-course experiment was designed utilizing the kumquat/Xcc pathosystem. Six independent Xcc or mock-inoculated kumquat plants were used; each plant was considered an independent biological replicate. Since citrus canker is a non-systemic disease, 6-10 leaves per treated kumquat plant were independently infiltrated using $5 \times 10^{8} \mathrm{cfu} / \mathrm{ml} \mathrm{Xcc}$. All RNA samples isolated from healthy mock- or Xcc inoculated (infected) leaves were processed independently. It is unlikely that differential gene expression observed was caused by the pressure infiltration inoculation method used, since this factor was normalized by treating the mock inoculated plants in the exact same way as infected plants.

Individual leaves were harvested from the inoculated and mock-inoculated plants at specific time-points postinoculation (pi) according to designated conditions for each experiment; there were 3 time points for the microarray experiment and 5 for subsequent real-time PCR assays. For the microarray experiment, the three time points (6 hpi, $24 \mathrm{hpi}$, and $72 \mathrm{hpi}$ ) were chosen based upon the internal bacterial populations previously detected at these times following inoculation and the knowledge that kumquat leaves abscised 3-5 days after inoculation. In addition, previous experiments revealed that there were some transcripts differentially expressed as early as $30 \mathrm{~min}$ post-inoculation with Xcc. Finally, the RNA yield and the abundance of cellular transcripts decreased as the leaves approached total PCD, as has been shown previously by others [53]. Time points of 0 and 120 hpi were added for the real time PCR assays. The healthy mock-inoculated and Xcc-inoculated leaf samples were immediately frozen in liquid nitrogen. For each respective time point, total RNA was extracted using RNeasy columns (QIAGEN, Valencia, CA, U.S.A.) according to the manufacturer's protocol. RNA purity, concentration and quality were assessed using a spectrophotometer and a BioAnalyzer 2100 (Agilent Technologies, Palo Alto, CA). 


\section{Fluorescent probe, hybridization, and scanning}

Prior to slide hybridization with probe, slides were prehybridized in a solution containing $5 \times$ SSC, $0.1 \%$ SDS and $1 \%$ bovine serum albumin at $42^{\circ} \mathrm{C}$ for $45 \mathrm{~min}$ to eliminate nonspecific binding of the probe to the slide. Slides were washed using MilliQ RNase free water, then isopropanol, once each, and air-dried. Slides were maintained at the hybridization temperature until loaded with probe. cDNA labeling was performed using the Genisphere (Hatfield, PA, USA) 3DNA Array50 ${ }^{\circledR}$ Expression Array Detection Kit according to the manufacturer's protocol for total RNA. For each time-point $125 \mu \mathrm{g}$ of DNA-free total RNA isolated from an independent plant (biological replicate) per slide was reverse transcribed for each of the mock inoculated and the infected leaf samples separately using Ambion reverse transcriptase (Ambion; LaJolla, CA) in the presence of Genisphere dT primers. Two-step hybridization was performed as follows. The first hybridization, carried out at $48^{\circ} \mathrm{C}$ overnight, contained $10 \mu \mathrm{l}$ of the concentrated cDNA (heat denatured probe) made using either the Cy5-RT primer capture sequence or the Cy3-RT primer capture sequence, in Genisphere $2 \times$ formamide-based hybridization buffer. Three successive post hybridization washes were performed, first in $2 \mathrm{X}$ SSC, $0.2 \%$ SDS at $55^{\circ} \mathrm{C}$ for $10 \mathrm{~min}$, then $2 \times \mathrm{SSC}$ for $10 \mathrm{~min}$ and finally in $0.2 \times$ SSC for $10 \mathrm{~min}$ at room temperature. The second hybridization (for addition of the dye) was performed using $2.5 \mu \mathrm{l}$ of either Cy3 or Cy5 dendrimer, $2 \mu \mathrm{l}$ of high-end differential buffer and $58 \mu \mathrm{l}$ of hybridization buffer. For each time point, three mock-inoculated samples from three individual plants were labeled with $\mathrm{Cy}-3$ and the Xcc infected samples were labeled with $\mathrm{Cy}-5$ and both were hybridized to the same array. Post-hybridization washes were conducted as performed earlier following the primary hybridization, with the addition of $0.1 \mathrm{ml}$ dithiothreitol (DTT) into the first and second wash solutions to reduce oxidation of fluorescent dyes.

\section{cDNA microarray setup and quality control}

Control measures such as the detection sensitivity level were determined using internal control probes and nonspecific control elements. Human genomic DNA, the green fluorescent protein gene, and the lambda control template DNA fragment were included as negative controls. Additionally, cDNAs previously implicated in pathogen defence such as PR1 and NPR1 from Arabidopsis, NDR1 from citrus, were printed 3 times on the array to test the ability of the microarray method to detect changes in gene expression. These were considered to be specific positive controls. In addition, the microarray ratio for each gene analyzed was normalized against the microarray ratio obtained for $18 \mathrm{~S}$.

\section{Transcriptome data analysis}

Agilent's Feature Extraction Software (Agilent Corp., Palo Alto, CA) was used to analyze the microarray data. Data were uploaded into the statistical platform R [77] for statistical analysis and the Limma package was used for pre-processing. Data were Lowes transformed followed by scaling between arrays [78]. Two array slides were chosen for each time-point experiment based on the consistency of the signal across the replicates. The fold difference in expression was computed as: 2 \average ratio (2 to the power of the average ratio). cDNAs with an average ratio of 1.0 or higher were considered differentially expressed, which represents a 1.5 fold or higher difference in expression. Statistical analysis was performed using two different approaches. Time-dependent gene expression changes were analyzed by the maSigPro methodology [79]. Data were subsequently subjected to ASCA-gene analysis that combines ANOVA and multivariate methods to identify main and secondary patterns of gene expression associated with different experimental factors [34]. Statistical analysis identified a number of selected genes that were further grouped into clusters.

Functional information about the ESTs represented in the array was obtained by Blast2GO analysis using default parameters [29]. Blast2GO uses Blast and an elaborated annotation algorithm to assign Gene Ontology (GO), Enzyme Code and InterPro functional labels to a set of uncharacterized sequences [27]. The functional characterization of these clusters was done by applying the Functional Enrichment (FE) method included in Blast2GO which implements the Gossip algorithm. FE methods assess which functional categories are over-represented within a group of genes in relation to a broader list, in this case the whole kumquat array. Finally, the major induced transcriptional changes considered functional classes as a whole were studied with the PCA-maSigFun method [80]. This method combines Principal Component Analysis and maSigPro to characterize the "expression profiles" associated with cellular functions. Sequence data from this work have been deposited in the NCBI Genbank database libraries (http://www.ncbi.nlm.nih.gov/ GenBank/index.html), using the BankIt dbEST database, and accession numbers were obtained. [Genbank: GW687757to GW690680]. (See Additional File 11).

\section{Quantitative Real-time Quantitative PCR}

Kumquat leaves were infiltrated with Xcc $\left(5 \times 10^{8} \mathrm{cfu}\right.$ per milliliter), then total RNA was isolated from inoculated leaves $0,6,24,72,120$ hpi for both the microarray and the quantitative real-time PCR experiment as previously stated in the 'experimental plan'. 
Total RNA was isolated separately for each respective time point using the TRIzol reagent (Invitrogen, Carlsbad,CA, U.S.A.) according to manufacturer's instructions. RNA samples were further purified using the RNeasy Plant Mini Kit (Qiagen, Valencia, CA) including DNaseI TURBO DNase (Ambion, Austin, TX, U.S.A.) treatment according to the manufacturer's instructions. RNA quality and quantity was then assessed using microspectrophotometry (Nanodrop Technologies, Inc., Wilmington, DE). cDNA was synthesized from $1 \mu \mathrm{g}$ of total RNA using Applied Biosystems (High Capacity cDNA Reverse Transcription Kit PN 4368813, 4374966). A TaqMan gene expression assay was then used to validate the transcript accumulation levels of a specific subset of genes from the kumquat microarrays. Reactions were performed in the ABI Prism7900 HT sequence detector (Applied Biosystems, Foster City, CA, U.S.A.). Primers for qRT-PCR were designed using the Primer Express 3.0 software (Applied Biosystems), and data were normalized using a Taqman ribosomal RNA control, in addition to the kumquat $18 \mathrm{~S}$ ribosomal gene that served as an internal control where each real-time PCR reaction was done in parallel with the $18 \mathrm{~S}$ primers. For internal controls, a number of genes, for example actin showed inconsistencies. The $18 \mathrm{~s}$ surprisingly showed coherency throughout the interaction, and this was noticed during the microarrays and was subsequently confirmed with the Realtime PCR (RT-qPCR) $18 \mathrm{~S}$ expression curve. qRT-PCR was carried out at $50^{\circ} \mathrm{C}$ for 2 minutes, $95^{\circ} \mathrm{C}$ for 10 minutes, followed by 40 cycles at $95^{\circ} \mathrm{C}$ for 15 seconds and $60^{\circ} \mathrm{C}$ for 1 minute.

\section{Additional material}

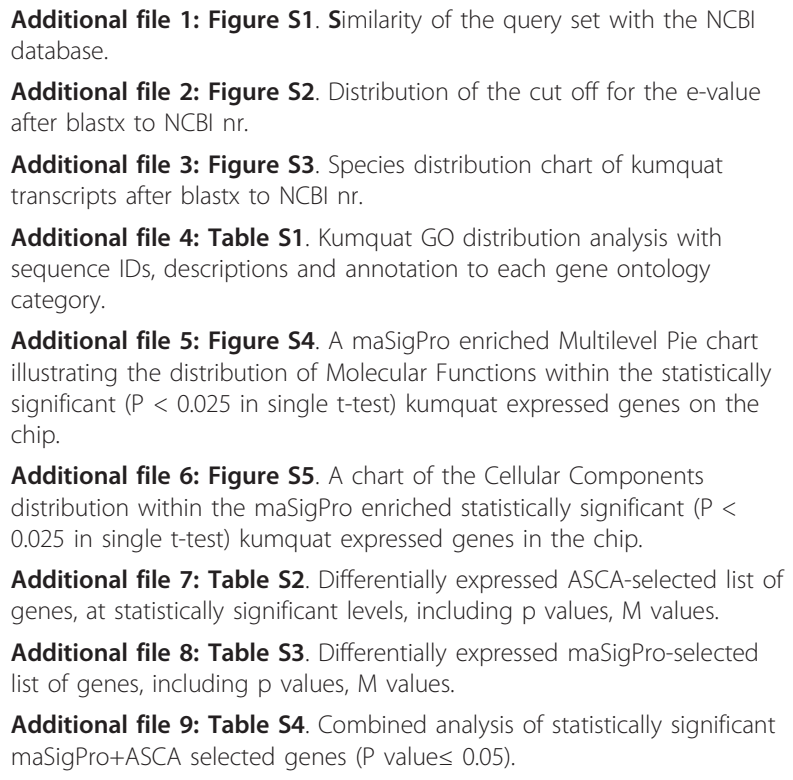

Additional file 6: Figure S5. A chart of the Cellular Components distribution within the maSigPro enriched statistically significant ( $P<$ 0.025 in single t-test) kumquat expressed genes in the chip.

Additional file 7: Table S2. Differentially expressed ASCA-selected list of genes, at statistically significant levels, including $p$ values, $M$ values.

Additional file 8: Table S3. Differentially expressed maSigPro-selected list of genes, including $\mathrm{p}$ values, $\mathrm{M}$ values.

Additional file 9: Table S4. Combined analysis of statistically significant maSigPro+ASCA selected genes ( $P$ value $\leq 0.05$ ).

Additional file 10: Figure S6. Quantitative realtime PCR ( $q R T-P C R$ ) analyses of six selected kumquat ESTs (AAM60932 ABM67698, AA089566, AAk81874, AAC35981, AAV91900) in kumquat inoculated with Xanthomonas axonopodis pv. citri strain using a $\left(5 \times 10^{8} \mathrm{cfu} / \mathrm{ml}\right)$ concentration of the Miami A strain X04-59. Leaf tissue was sampled for both inoculated and mock-inoculated plants at 0, 6, 24, 48, 72 and 120 hpi. (An average of three independent biological replications).

Additional file 11: Table S5. Sequence data from this work have been deposited in the NCBI Genbank database libraries [Genbank: GW687757to GW690680].

\section{Acknowledgements and Funding}

This research was supported in part by the Citrus Research and Education Center (CREC), Dr. Frederick Gmitter, Jr. and by a grant from the Florida Citrus Production Research Advisory Council, Florida Department of Citrus (FDACS Contract Number 67), "Peter McClure, Chairman".

We gratefully acknowledge the generous financial and intellectual support from Florida citrus growers, Mrs. Hariot and Mr.Barnette E. "Barney" Greene Jr. that helped complete this work.

We would also like to thank Dr. Henry Baker, Professor and Interim Chair and Dr. Hassan Badrane (Medicine: Molecular Genetics and Microbiology Dept at UF) for providing help with microarrays equipments. We would also like to thank Dr. Jeffrey Jones and Dr. Vicente Febres for their objective critical review of the manuscript.

\section{Author details}

${ }^{1}$ Plant Molecular and Cellular Biology Program (PMCB), Horticultural Sciences Department, University of Florida, Gainesville, Fl., 32611,USA. ²PMCB, Citrus Research and Education Center, University of Florida, Lake Alfred, Fl., USA. ${ }^{3}$ Centro de Investigación Príncipe Felipe,Valencia, SPAIN.

\section{Authors' contributions}

AK carried out the molecular genetic studies, participated in data analysis, and drafted the manuscript. AC carried out the B2GO statistical analysis supervised by JD. FG participated in the design of the study in addition to coordination between the authors and review of the manuscript. GM participated in its experimental design and reviewed the manuscript. All authors read and approved the final manuscript.

Received: 22 June 2011 Accepted: 11 November 2011

Published: 11 November 2011

\section{References}

1. Gottwald TR, Graham JH, Schubert TS: Citrus canker: The pathogen and its impact. Online Plant Health Progress 2002.

2. Głowacki S, Macioszek $V$, Kononowicz A: R proteins as fundamentals of plant innate immunity. Cellular \&amp; Molecular Biology Letters 2010, 1-24.

3. Jones JD, Dangl JL: The plant immune system. Nature 2006, 444(7117):323-329.

4. Fujikawa $T$, Ishihara $H$, Leach JE, Tuyumu S: Suppression of defense response in plants by avrBs3/pthA gene family of Xanthomonas spp. MolPlant-Microbe Interact 2006, 19:342-349.

5. Yang B, Sugio A, White FF: Avoidance of host recognition by alterations in the repetitive and C-terminal regions of AvrXa7, a type III effector of Xanthomonas oryzae pv. oryzae. Mol Plant Microbe Interact 2005, 18(2):142-149.

6. Alfano JR, Collmer A: The type III (Hrp) secretion pathway of plant pathogenic bacteria: trafficking harpins, Avr proteins, and death. $J$ Bacteriol 1997, 179(18):5655-5662.

7. Sanabria N, Goring D, Nurnberger T, Dubery I: Self/nonself perception and recognition mechanisms in plants: a comparison of self-incompatibility and innate immunity. New Phytol 2008, 178(3):503-514.

8. Gottig N, Garavaglia BS, Daurelio LD, Valentine A, Gehring C, Orellano EG, Ottado J: Xanthomonas axonopodis pv. citri uses a plant natriuretic peptide-like protein to modify host homeostasis. Proc Natl Acad Sci USA 2008, 105(47):18631-18636.

9. Bestwick CS, Brown IR, Bennett MH, Mansfield JW: Localization of hydrogen peroxide accumulation during the hypersensitive reaction of 
lettuce cells to Pseudomonas syringae pv phaseolicola. Plant Cell 1997, 9(2):209-221.

10. Ali R, Ma W, Lemtiri-Chlieh F, Tsaltas D, Leng Q, von Bodman S, Berkowitz GA: Death don't have no mercy and neither does calcium: Arabidopsis CYCLIC NUCLEOTIDE GATED CHANNEL2 and innate immunity. Plant Cell 2007, 19(3):1081-1095.

11. Shiotani H, Fujikawa T, Ishihara H, Tsuyumu S, Ozaki K: A pthA homolog from Xanthomonas axonopodis pv. citri responsible for host-specific suppression of virulence. J Bacteriol 2007, 189(8):3271-3279.

12. Brunings AM, Gabriel DW: Xanthomonas citri: breaking the surface. Molecular Plant Pathology 2003, 4(3):141-157.

13. Romer P, Hahn S, Jordan T, Strauss T, Bonas U, Lahaye T: Plant pathogen recognition mediated by promoter activation of the pepper Bs3 resistance gene. Science 2007, 318(5850):645-648.

14. Yang B, White FF: Diverse members of the AvrBs3/PthA family of type III effectors are major virulence determinants in bacterial blight disease of rice. Mol Plant Microbe Interact 2004, 17(11):1192-1200.

15. Duan YP, A C, G Z, G E, Gabriel DW: Expression of a single, host-specific, bacterial pathogenicity gene in plant cells elicits division, enlargement, and cell death. Molecular Plant-Microbe Interactions 1999, 12(6):556-560.

16. Tasic $L$, Borin PF, Khater $L C$, Ramos $C H$ : Cloning and characterization of three hypothetical secretion chaperone proteins from Xanthomonas axonopodis pv. citri. Protein Expr Purif 2007, 53(2):363-369.

17. White FF, Potnis N, Jones JB, Koebnik R: The type III effectors of Xanthomonas. Mol Plant Pathol 2009, 10(6):749-766.

18. Schenk PM, Kazan K, Manners JM, Anderson JP, Simpson RS, Wilson IW, Somerville SC, Maclean DJ: Systemic gene expression in Arabidopsis during an incompatible interaction with Alternaria brassicicola. Plant Physiol 2003, 132(2):999-1010

19. Spoel SH, Dong X: Making sense of hormone crosstalk during plant immune responses. Cell Host Microbe 2008, 3(6):348-351.

20. Lorenzo O, Piqueras R, Sanchez-Serrano JJ, Solano R: ETHYLENE RESPONSE FACTOR1 integrates signals from ethylene and jasmonate pathways in plant defense. Plant Cell 2003, 15(1):165-178.

21. Nemhauser JL, Hong F, Chory J: Different plant hormones regulate similar processes through largely nonoverlapping transcriptional responses. Cell 2006, 126(3):467-475.

22. Glazebrook J: Use of microarray analysis to dissect the plant defense response. Methods Mol Biol 2007, 354:121-130.

23. Leon-Reyes A, Spoel SH, De Lange ES, Abe H, Kobayashi M, Tsuda S, Millenaar FF, Welschen RA, Ritsema T, Pieterse CM: Ethylene Modulates the Role of NPR1 in Cross-Talk Between Salicylate and Jasmonate Signaling. Plant Physiol 2009

24. Khalaf AA, Moore GA, Jones JB, Gmitter FG Jr: New insights into the resistance of Nagami kumquat to canker disease. Physiological and Molecular Plant Pathology 2007, 71:240-250.

25. Alfano JR, Collmer A: Bacterial pathogens in plants: Life up against the wall. Plant Cell 1996, 8(10):1683-1698.

26. Alba R, Fei Z, Payton P, Liu Y, Moore SL, Debbie P, Cohn J, D'Ascenzo M, Gordon JS, Rose JK, et al: ESTs, CDNA microarrays, and gene expression profiling: tools for dissecting plant physiology and development. Plant J 2004, 39(5):697-714.

27. Gotz S, Garcia-Gomez JM, Terol J, Williams TD, Nagaraj SH, Nueda MJ, Robles M, Talon M, Dopazo J, Conesa A: High-throughput functional annotation and data mining with the Blast2GO suite. Nucleic Acids Res 2008, 36(10):3420-3435.

28. Talon M, Gmitter FG Jr: Citrus genomics. Int J Plant Genomics 2008, 2008:528361.

29. Conesa A, Gotz S, Garcia-Gomez JM, Terol J, Talon M, Robles M: Blast2GO: a universal tool for annotation, visualization and analysis in functional genomics research. Bioinformatics 2005, 21(18):3674-3676.

30. Cohn JR, Martin GB: Pseudomonas syringae pv. tomato type III effectors AvrPto and AvrPtoB promote ethylene-dependent cell death in tomato. Plant J 2005, 44(1):139-154.

31. Desikan R, S AH-M, Hancock JT, Neill SJ: Regulation of the Arabidopsis transcriptome by oxidative stress. Plant Physiol 2001, 127(1):159-172.

32. Gang DR, Wang J, Dudareva N, Nam KH, Simon JE, Lewinsohn E, Pichersky E: An investigation of the storage and biosynthesis of phenylpropenes in sweet basil. Plant Physiol 2001, 125(2):539-555.

33. Conesa A, Gotz S: Blast2GO: A comprehensive suite for functional analysis in plant genomics. Int J Plant Genomics 2008, 2008:619832.
34. Nueda MJ, Conesa A, Westerhuis JA, Hoefsloot HC, Smilde AK, Talon M, Ferrer A: Discovering gene expression patterns in time course microarray experiments by ANOVA-SCA. Bioinformatics 2007, 23(14):1792-1800.

35. Kay S, Hahn S, Marois E, Hause G, Bonas U: A Bacterial Effector Acts as a Plant Transcription Factor and Induces a Cell Size Regulator. Science 2007, 318(5850):648-651

36. Cernadas RA, Camillo LR, Benedetti CE: Transcriptional analysis of the sweet orange interaction with the citrus canker pathogens Xanthomonas axonopodis pv. citri and Xanthomonas axonopodis pv. aurantifolii. Mol Plant Pathol 2008, 9(5):609-631.

37. Albrecht U, Bowman KD: Transcriptional response of susceptible and tolerant citrus to infection with Candidatus Liberibacter asiaticus. Plant Science 2011.

38. Ross J, Li Y, Lim E, Bowles DJ: Higher plant glycosyltransferases. Genome Biol 2001, 2(2), Reviews 3004.

39. Dixon RA: Natural products and plant disease resistance. Nature 2001, 411(6839):843-847.

40. Mugford ST, Qi X, Bakht S, Hill L, Wegel E, Hughes RK, Papadopoulou K, Melton R, Philo M, Sainsbury F, et al: A serine carboxypeptidase-like acyltransferase is required for synthesis of antimicrobial compounds and disease resistance in oats. Plant Cell 2009, 21(8):2473-2484.

41. Nanda AK, Andrio E, Marino D, Pauly N, Dunand C: Reactive Oxygen Species during plant-microorganism early interactions. Journal of Integrative Plant Biology 2010, 52(2):195-204.

42. Torres MA: ROS in biotic interactions. Physiologia Plantarum 2010, 138(4):414-429.

43. de Pinto MC, Paradiso A, Leonetti P, De Gara L: Hydrogen peroxide, nitric oxide and cytosolic ascorbate peroxidase at the crossroad between defence and cell death. Plant J 2006, 48(5):784-795.

44. Vranova E, Inze D, Van Breusegem F: Signal transduction during oxidative stress. J Exp Bot 2002, 53(372):1227-1236.

45. Kuzniak E, Sklodowska M: The effect of Botrytis cinerea infection on the antioxidant profile of mitochondria from tomato leaves. J Exp Bot 2004, 55(397):605-612

46. Halliwell B, Foyer $\mathrm{CH}$ : Ascorbic acid, metal ions and the superoxide radical. Biochem J 1976, 155(3):697-700.

47. Foyer $\mathrm{CH}$, Noctor $\mathrm{G}$ : Redox homeostasis and antioxidant signaling: a metabolic interface between stress perception and physiological responses. Plant Cell 2005, 17(7):1866-1875.

48. Trumper S, Follmann H, Haberlein I: A novel-dehydroascorbate reductase from spinach chloroplasts homologous to plant trypsin inhibitor. FEBS Lett 1994, 352(2):159-162.

49. Yang C-W, Gonzalez-Lamothe R, Ewan RA, Rowland O, Yoshioka H, Shenton M, Ye H, O'Donnell E, Jones JDG, Sadanandom A: The E3 ubiquitin ligase activity of Arabidopsis PLANT U-BOX17 and Its functional tobacco Homolog ACRE276 are required for cell death and defense. Plant Cell 2006, 18(4):1084-1098.

50. Trujillo M, Ichimura K, Casais C, Shirasu K: Negative regulation of PAMPtriggered immunity by an E3 ubiquitin ligase triplet in Arabidopsis. Curr Biol 2008, 18(18):1396-1401.

51. Bonfig KB, Schreiber U, Gabler A, Roitsch T, Berger S: Infection with virulent and avirulent $\mathrm{P}$. syringae strains differentially affects photosynthesis and sink metabolism in Arabidopsis leaves. Planta 2006, 225(1):1-12.

52. Mysore KS, D'Ascenzo MD, He X, Martin GB: Overexpression of the disease resistance gene Pto in tomato induces gene expression changes similar to immune responses in human and fruitfly. Plant Physiol 2003, 132(4):1901-1912.

53. Quirino BF, Noh YS, Himelblau E, Amasino RM: Molecular aspects of leaf senescence. Trends Plant Sci 2000, 5(7):278-282.

54. Albert M, Werner M, Proksch P, Fry SC, Kaldenhoff R: The cell wallmodifying xyloglucan endotransglycosylase/hydrolase LeXTH1 is expressed during the defence reaction of tomato against the plant parasite Cuscuta reflexa. Plant Biol (Stuttg) 2004, 6(4):402-407.

55. Zhu-Salzman K, Salzman RA, Ahn JE, Koiwa H: Transcriptional regulation of sorghum defense determinants against a phloem-feeding aphid. Plant Physiol 2004, 134(1):420-431.

56. Lee S, Kim SY, Chung E, Joung YH, Pai HS, Hur CG, Choi D: EST and microarray analyses of pathogen-responsive genes in hot pepper (Capsicum annuum L.) non-host resistance against soybean pustule pathogen (Xanthomonas axonopodis pv. glycines). Funct Integr Genomics 2004, 4(3):196-205 
57. Brunner F, Stintzi A, Fritig B, Legrand M: Substrate specificities of tobacco chitinases. Plant J 1998, 14(2):225-234.

58. Kasprzewska A: Plant chitinases-regulation and function. Cell Mol Biol Lett 2003, 8(3):809-824

59. Lebel E, Heifetz $P$, Thorne L, Uknes $S$, Ryals J, Ward E: Functional analysis of regulatory sequences controlling PR-1 gene expression in Arabidopsis. Plant J 1998, 16(2):223-233.

60. Mitsuhara I, Iwai T, Seo S, Yanagawa Y, Kawahigasi H, Hirose S, Ohkawa Y, Ohashi Y: Characteristic expression of twelve rice PR1 family genes in response to pathogen infection, wounding, and defense-related signal compounds (121/180). Molecular genetics and genomics: MGG 2008, 279(4):415-427.

61. Campos MA, Rosa DD, Teixeira JÉC, Targon MLPN, Souza AA, Paiva LV, Stach-Machado DR, Machado MA: PR gene families of citrus: their organ specific-biotic and abiotic inducible expression profiles based on ESTs approach. Genetics and Molecular Biology 2007, 30:917-930.

62. Li C-W, Su R-C, Cheng C-P, You S-J, Hsieh T-H, Chao T-C, Chan M-T: Tomato RAV Transcription Factor Is a Pivotal Modulator Involved in the AP2/ EREBP-Mediated Defense Pathway. Plant Physiology 2011, 156(1):213-227.

63. Dodds PN, Lawrence GJ, Ellis JG: Six amino acid changes confined to the leucine-rich repeat beta-strand/beta-turn motif determine the difference between the P and P2 rust resistance specificities in flax. Plant Cell 2001, 13(1):163-178.

64. Pontier D, Godiard L, Marco Y, Roby D: hsr203J, a tobacco gene whose activation is rapid, highly localized and specific for incompatible plant/ pathogen interactions. Plant J 1994, 5(4):507-521.

65. Clough SJ, Fengler KA, Yu IC, Lippok B, Smith RK Jr, Bent AF: The Arabidopsis dnd1 "defense, no death" gene encodes a mutated cyclic nucleotide-gated ion channel. Proc Natl Acad Sci USA 2000, 97(16):9323-9328.

66. Green DR, Reed JC: Mitochondria and apoptosis. Science 1998, 281(5381):1309-1312.

67. Logan DC: The dynamic plant chondriome. Seminars in Cell \& Developmental Biology 2010, 21(6):550-557.

68. Martinou J-C, Desagher S, Antonsson B: Cytochrome c release from mitochondria: all or nothing. Nat Cell Biol 2000, 2(3):E41-E43.

69. Sanchez P, de Torres Zabala M, Grant M: AtBI-1, a plant homologue of Bax inhibitor-1, suppresses Bax-induced cell death in yeast and is rapidly upregulated during wounding and pathogen challenge. Plant J 2000, 21(4):393-399.

70. Hoeberichts FA, Woltering EJ: Multiple mediators of plant programmed cell death: Interplay of conserved cell death mechanisms and plantspecific regulators. BioEssays 2003, 25(1):47-57.

71. Li J, Brader G, Palva ET: Kunitz trypsin inhibitor: an antagonist of cell death triggered by phytopathogens and fumonisin b1 in Arabidopsis. Mol Plant 2008, 1(3):482-495.

72. Xu R, Song F, Zheng Z: OsBISAMT1, a gene encoding S-adenosyl-Lmethionine: salicylic acid carboxyl methyltransferase, is differentially expressed in rice defense responses. Mol Biol Rep 2006, 33(3):223-231.

73. Kumar D, Klessig DF: High-affinity salicylic acid-binding protein 2 is required for plant innate immunity and has salicylic acid-stimulated lipase activity. Proc Natl Acad Sci USA 2003, 100(26):16101-16106.

74. Gibly A, Bonshtien A, Balaji V, Debbie P, Martin GB, Sessa G: Identification and expression profiling of tomato genes differentially regulated during a resistance response to Xanthomonas campestris pv. vesicatoria. Mol Plant Microbe Interact 2004, 17(11):1212-1222.

75. Lund ST, Stall RE, Klee HJ: Ethylene regulates the susceptible response to pathogen infection in tomato. Plant Cell 1998, 10(3):371-382.

76. Heller RA, Schena M, Chai A, Shalon D, Bedilion T, Gilmore J, Woolley DE, Davis RW: Discovery and analysis of inflammatory disease-related genes using CDNA microarrays. Proc Natl Acad Sci USA 1997, 94(6):2150-2155.

77. Smyth GK, (ed): Limma: Linear models for microarray data. New York: Springer; 2005.

78. Yang YH, Dudoit S, Luu P, Lin DM, Peng V, Ngai J, Speed TP: Normalization for CDNA microarray data: a robust composite method addressing single and multiple slide systematic variation. Nucleic Acids Res 2002, 30(4):e15.

79. Conesa A, Nueda MJ, Ferrer A, Talon M: maSigPro: a method to identify significantly differential expression profiles in time-course microarray experiments. Bioinformatics 2006, 22(9):1096-1102.
80. Nueda MJ, Sebastian P, Tarazona S, Garcia-Garcia F, Dopazo J, Ferrer A, Conesa A: Functional assessment of time course microarray data. BMC Bioinformatics 2009, 10(Suppl 6):S9.

doi:10.1186/1471-2229-11-159

Cite this article as: Khalaf et al:: Fortunella margarita Transcriptional Reprogramming Triggered by Xanthomonas citri subsp. citri. BMC Plant Biology 2011 11:159.

\section{Submit your next manuscript to BioMed Central and take full advantage of:}

- Convenient online submission

- Thorough peer review

- No space constraints or color figure charges

- Immediate publication on acceptance

- Inclusion in PubMed, CAS, Scopus and Google Scholar

- Research which is freely available for redistribution

Submit your manuscript at www.biomedcentral.com/submit
Ciomed Central 